\title{
Filamentous cyanobacteria preserved in masses of fungal hyphae from the Triassic of Antarctica
}

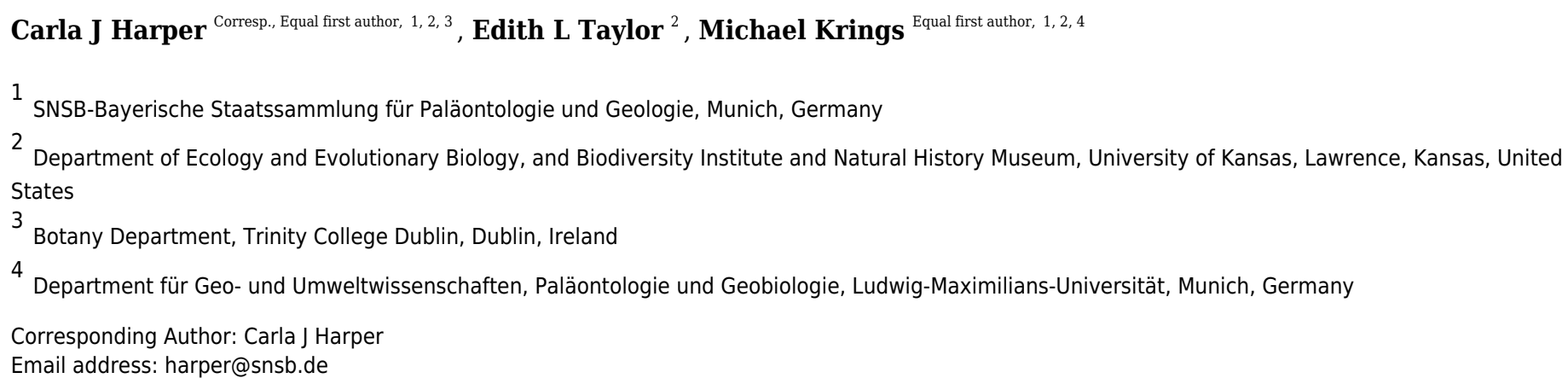

Permineralized peat from the central Transantarctic Mountains of Antarctica has provided a wealth of information on plant and fungal diversity in Middle Triassic high-latitude forest paleoecosystems; however, there are no reports as yet of algae or cyanobacteria. The first record of a fossil filamentous cyanobacterium in this peat consists of wide, uniseriate trichomes composed of discoid cells up to $25 \mu \mathrm{m}$ wide, and enveloped in a distinct sheath. Filament morphology, structurally preserved by permineralization and mineral replacement, corresponds to the fossil genus Palaeolyngbya, a predominantly Precambrian equivalent of the extant Lyngbya sensu lato (Oscillatoriaceae, Oscillatoriales). Specimens occur exclusively in masses of interwoven hyphae produced by the fungus Endochaetophora antarctica, suggesting that a special micro-environmental setting was required to preserve the filaments. Whether some form of symbiotic relationship existed between the fungus and cyanobacterium remains unknown. 


\section{Filamentous cyanobacteria preserved in masses of}

2 fungal hyphae from the Triassic of Antarctica

3

4

5 Carla J. Harper ${ }^{1,2,3}$, Edith L. Taylor ${ }^{2}$, Michael Krings ${ }^{1,2,4}$

6

7 'SNSB-Bayerische Staatssammlung für Paläontologie und Geologie, Richard-Wagner-Straße 10,

880333 Munich, Germany

$9 \quad{ }^{2}$ Department of Ecology and Evolutionary Biology, University of Kansas, and Biodiversity

10 Institute and Natural History Museum, University of Kansas, Lawrence, KS 66045-7534, USA

$11{ }^{3}$ Botany Department, School of Natural Sciences, Trinity College Dublin, Dublin 2, Ireland

${ }^{4}$ Department für Geo- und Umweltwissenschaften, Paläontologie und Geobiologie, LudwigMaximilians-Universität, Richard-Wagner-Straße 10, 80333 Munich, Germany

Corresponding Author:

Carla J. Harper

Richard-Wagner-Straße 10, 80333 Munich, Germany

Email address: harper@snsb.de 


\section{Abstract}

24 Permineralized peat from the central Transantarctic Mountains of Antarctica has provided a wealth 25 of information on plant and fungal diversity in Middle Triassic high-latitude forest 26 paleoecosystems; however, there are no reports as yet of algae or cyanobacteria. The first record 27 of a fossil filamentous cyanobacterium in this peat consists of wide, uniseriate trichomes composed 28 of discoid cells up to $25 \mu \mathrm{m}$ wide, and enveloped in a distinct sheath. Filament morphology, 29 structurally preserved by permineralization and mineral replacement, corresponds to the fossil 30 genus Palaeolyngbya, a predominantly Precambrian equivalent of the extant Lyngbya sensu lato

31 (Oscillatoriaceae, Oscillatoriales). Specimens occur exclusively in masses of interwoven hyphae 32 produced by the fungus Endochaetophora antarctica, suggesting that a special micro33 environmental setting was required to preserve the filaments. Whether some form of symbiotic 34 relationship existed between the fungus and cyanobacterium remains unknown.

37 Keywords: Endochaetophora antarctica, fungal reproduction, lichen, Mesozoic, Mucoromycota, 38 Oscillatoriaceae, Palaeolyngbya, peat, symbiosis 
46

47 Cyanobacteria, one of the most successful groups of prokaryotic microorganisms on Earth, were instrumental in the oxygenation of the atmosphere and, as primary producers and nitrogen-fixers,

were and are prominent contributors to Earth's nutrient cycles (Knoll, 2008). The fossil record of these life forms is extensive and varied, with a peak of documented morphologies and formally described taxa in the Proterozoic ( 2.54-0.54 Ga) (Tomitani et al., 2006; Knoll, 2008; Schopf, 2012).

Fossil cyanobacterial filaments that correspond in morphology to the modern genus Lyngbya (Komárek et al., 2014; Guiry \& Guiry, 2019) are ordinarily assigned to Palaeolyngbya, a fossil taxon for wide, unbranched filaments composed of cylindrical trichomes with discoid cells several times wider than long, and colorless sheaths (e.g. Schopf, 1968). Palaeolyngbya is primarily Proterozoic and Cambrian in age (see references in Butterfield, Knoll \& Swett, 1994; Sergeev, Sharma \& Shukla, 2012). However, exquisitely preserved specimens have been reported recently from the Lower Devonian Rhynie chert (Krings, 2019), and there is also one record from the Permian of China (Liu \& Li, 1986: pl. 1, fig. 5). The genus has not yet been documented from the Mesozoic, whereas Cenozoic fossils and subfossil specimens are commonly assigned to Lyngbya, (e.g. Waggoner, 1994; Stankevica et al., 2015).

Permineralized peat from Fremouw Peak in the central Transantarctic Mountains, Antarctica, represents a unique source of new information on Middle Triassic (240 Ma) highlatitude swamp-forest ecosystems. The peat contains an exceptionally diverse structurally preserved flora (reviewed by Escapa et al., 2011; Bomfleur et al., 2013, 2014; Decombeix et al., 2014), together with numerous examples of fungi and fungus-like organisms (reviewed by Harper et al., 2016). However, no evidence of the occurrence of photoautotrophic microorganisms, such 
69 as cyanobacteria and eukaryotic algae, in the Fremouw Peak permineralized peat has been 70 discovered to date.

71 This paper presents the first record of a filamentous cyanobacterium from the Fremouw

72 Peak permineralized peat. Specimens are similar morphologically to Palaeolyngbya kerpii from

73 the Lower Devonian Rhynie chert (Krings, 2019), and to several Proterozoic species of that genus

74 (Schopf, 1968; Butterfield, Knoll \& Swett, 1994; Sergeev, Sharma \& Shukla, 2012). The Antarctic

75 filaments all occur within masses of interwoven hyphae produced by a fungus. This discovery is

76 important because it provides insights into the taphonomic circumstances that appear to be

77 imperative to the preservation of cyanobacteria in permineralized peat.

79 Material \& Methods

80 Data were collected from the same locality previously described in Harper et al. (2015), 81 specifically the fossils occur in permineralized (silicified) peat from the Fremouw Formation in 82 the central Transantarctic Mountains of Antarctica (Taylor, Taylor \& Collinson, 1986; Cúneo et 83 al., 2003). The Fremouw Formation is a 620-750-m-thick siliclastic succession deposited by low 84 sinuosity braided streams (Faure \& Mensing, 2010). The fossils occur within several allochthonous 85 clasts that are at approximately the same stratigraphic level within a trough-crossbedded, medium86 grained, greenish-gray volcaniclastic sandstone. Permineralized peat is found at a single level at 87 the Fremouw Peak locality, approximately $30 \mathrm{~m}$ below the top of the formation (Figure 1). Chunks 88 of the peat were likely rafted into their current position during a flooding event that caused them 89 to be stranded on sand bars prior to permineralization (Taylor, Taylor \& Collinson, 1989) and 90 isolated into individual lenses within the outcrop. The peat became silicified after burial; the age 91 of the plant remains contained in the peat is equivalent to that of the surrounding clastic sediments, 
92 i.e. fluvial sandstone, which also contain trunks of wood of equivalent age to the peat (Decombeix

93 et al., 2014). The silica for the permineralization is interpreted to have come from the dissolution

94 of abundant siliceous, volcanic detritus from the upper Fremouw Formation (Taylor, Taylor \&

95 Collinson, 1989).

96 The exact age of the Fremouw Peak peat deposit remains uncertain. The peat and

97 surrounding material have been dated as Anisian (early Middle Triassic) based on palynomorphs

98 and nearby vertebrate fossils (Farabee, Taylor \& Taylor, 1990; Hammer, 1990; Sidor, Damiani \&

99 Hammer 2008; Faure \& Mensing, 2010). Recent detrital-zircon dating indicates that the base of

100 member B of the Fremouw Formation is $\sim 242.3 \pm 2.3 \mathrm{Ma}$ (= early Ladinian; see Elliott et al., 2017:

101 fig. 4), but the silicified peat is located in the younger member $\mathrm{C}$ of the Fremouw Formation. A

102 late Ladinian or possibly Carnian age is, therefore, more likely to be accurate for the Fremouw

103 Peak peat deposits (Bomfleur et al., 2014; Elliot et al., 2017).

104 The material used in this study was collected during the 2010-2011 austral summer

105 Antarctic field season. Peat blocks were cut into slabs and then immersed in $48 \%$ HF to dissolve

106 the silica. Acetate peels were produced from the etched surfaces by using the technique outlined

107 by Joy, Willis \& Lacey (1956) modified for hydrofluoric acid (Galtier \& Phillips, 1999).

108 Consecutive peels of promising specimens were mounted on microscope slides in Eukitt ${ }$. Other

109 slabs were cut into wafers and used for the preparation of thin sections (Hass \& Rowe, 1999), with

110 a thickness of 40-60 $\mu \mathrm{m}$. Wafers of the peat were cemented to a glass slide and then ground thin

111 enough to be viewed in transmitted light. Mounted peels and thin sections were analyzed with a

112 Leica DM LB2 transmitted light microscope at the highest possible total magnification $(400 \times$ or

$1131000 \times$ ); digital images were captured with a Leica DFC-480 camera and processed in Adobe

114 Photoshop CS5. When suitable specimens were identified, they were processed minimally (i.e. 
115 contrast, brightness, and focal stacking) and measurements were taken using Adobe Photoshop

116 CS6 Version 13.0 x64 (C1990-2012, Adobe Systems). When necessary, multiple images of the

117 same specimen were recorded at different focal planes and compiled to produce composite images,

118 (Kerp \& Bomfleur, 2011). The images were stacked in Adobe Photoshop CS6, and specific areas

119 were modified to reveal the complete three-dimensional image as seen in the thin section.

120 Composite images in this study are Figure 2A-C. Specimen and slides are deposited in the

121 Paleobotanical Collections, Biodiversity Institute, University of Kansas (KUPB) under specimen

122 accession numbers KUPB 17054, 17729 E Bot, 17729 F Top, and 18084, and slide numbers KUPB

$123 \quad 35,009-35,018$.

124

125 Results

126 Context and preservation

127 Systematic screening of permineralized peat from the Fremouw Peak locality has yielded several

128 hundred blocks of leaf mats that contain predominantly degraded Dicroidium leaves (Pigg, 1990)

129 ("L" in Figure 2A, B), rare pieces of fragmented Heidiphyllum (Axsmith, Taylor \& Taylor, 1998),

130 degraded plant axes, and intermixed detritus. Some of the leaves are surrounded by conspicuous

131 whitish areas, which are elongate oval or irregular in section view, 120-590 $\mu \mathrm{m}$ high, and up to 4

$132 \mathrm{~cm}$ wide. The whitish areas comprise densely interwoven, thin-walled, irregularly septate fungal

133 hyphae 2-6 $\mu \mathrm{m}$ wide (arrows in Figure 2C) embedded in what appears to be a gelatinous matrix.

134 More than $95 \%$ of these formations, henceforth called "hyphal masses," contain one or several

135 specimens of the enigmatic fungal reproductive unit Endochaetophora antarctica (Figure 2A, B),

136 formally described some 30 years ago based on dispersed specimens from the same locality (White

$137 \&$ Taylor, 1988, 1989). For a parallel study focusing on E. antarctica, we analyzed more than 50 
138 blocks of leaf mats based on thin sections, each containing between 1 and 15 hyphal masses. In

139 these blocks, approximately $25 \%$ of the larger masses containing fungal reproductive units also

140 contain large cyanobacterial filaments, which are described below. Endochaetophora antarctica

141 is characterized by a three-layered investment from which extend numerous prominent hollow,

142 tube-like appendages ( 4.5-10 $\mu \mathrm{m}$ wide and up to $130 \mu \mathrm{m}$ long) that branch regularly (Figure 2D,

143 E). Because the appendages are markedly different structurally from the cyanobacterial filaments,

144 the two structures cannot be confused. The cyanobacterial filaments are not body fossils as the

145 hyphal masses containing the fungal reproductive units, but rather represent (partial to full) mineral

146 infillings or coatings, which are orange to reddish or have grayish outlines (Figure 2F-J; $3 \mathrm{~A}-\mathrm{E}$ ).

147 Cyanobacterial filaments have not been found in the peat matrix surrounding the hyphal masses,

148 or elsewhere in the peat.

150 Cyanobacterial filaments

151 In the description of the fossil cyanobacterium, we use the terminology for filamentous

152 cyanobacteria outlined by Komárek, Kling \& Komárková (2003); trichomes with sheaths are

153 traditionally termed filaments. Preserved filament portions (arrows in Figure 2G-J) are up to 740

$154 \mu \mathrm{m}$ long and 17-31 $\mu \mathrm{m}$ wide, and consist of straight or somewhat curved, cylindrical, uniseriate,

155 and probably isopolar (i.e. no evidence indicative of heteropolarity has been found) trichomes of

156 relatively uniform, short discoid cells, enveloped in a distinct sheath (Figure 4A-C). Most of the

157 specimens demonstrate a regular pattern of discoid cells (or cell units), which are either empty or 158 contain homogenous opaque matter (cell contents), 22.8-25 $\mu \mathrm{m}$ wide and 3.8-5 $\mu \mathrm{m}$ high (which

159 equals a width-to-height ratio of 5:1) (Figure 4A). Other specimens, however, are preserved as

160 empty sheaths (Figure 4F), whereas in still others the cells are recognizable only through the 
161 arrangement of crystals (red to orange, or gray in appearance) (Figures 2G, 3A-E, 4E). Different

162 modes of cell and trichome preservation may also occur within the same filament (Figure 2F).

163 Sheaths are colorless, unornamented, and well-recognizable in all specimens. They range

164 in thickness from 1 to $4 \mu \mathrm{m}$; however, sheath thickness within one filament varies only by $1-1.5$

$165 \mu \mathrm{m}$. Stratification of the sheath is not recognizable in any of the specimens; external constrictions

166 or folds at cross walls are also not discernible. Most specimens represent intercalary trichome

167 portions that end bluntly and appear to have broken off. Compelling evidence of trichome tips has

168 not been found. There is a single poorly preserved specimen that appears to have a tapering tip

169 with a round end; however, it is difficult to be sure that this represents an actual trichome end

170 (Figure 3A, black arrow in $2 \mathrm{G}$ ). Unfortunately, the preservation of the filaments by mineral

171 replacement does not enable recognition of cell division patterns. One specimen shows possible

172 hormogonium formation (Figure 4D, E). This filament is the only example displaying a

173 pronounced constriction, and the cell at the constriction is umbilicated. One intercalary filament

174 portion approximately $87 \mu \mathrm{m}$ long might contain a necridium based on the presence of a pair of

175 differently shaped and colored cells (Figure 4B). No evidence has been found of (false) branching

176 and the formation of heterocysts or akinetes. For a graphical overview of the spatial distribution

177 of cyanobacterial filaments and E. antarctica within one of the hyphal masses, refer to Figure 5.

178

179 Discussion

180 The Triassic permineralized peat from Fremouw Peak has been studied intensively for more than

18145 years, (e.g. Schopf, 1973; Taylor, Taylor \& Collinson, 1989). Plant and fungal paleodiversity

182 have been documented in great detail based on large numbers of structurally preserved fossils (e.g.

183 Escapa et al., 2011; Harper et al., 2016), and the paleoecosystem has been reconstructed as a 
184 diverse peat-forming swamp forest dominated by corystospermalean seed ferns and voltzialean

185 conifers, with understory elements including the enigmatic Petriellales, ferns, and sphenophytes

186 (Taylor, Taylor \& Collinson, 1989; Escapa et al., 2011; Bomfleur et al., 2014; Decombeix et al.,

187 2014). However, there is not a single report of cyanobacteria from Fremouw Peak despite these

188 organisms being regular constituents of comparable modern peat-forming ecosystems (Jackson,

189 Liew \& Yule, 2009; Yule \& Gomez, 2009; Marsid et al., 2015). Fossils of cyanobacteria have been

190 described from Antarctica (Priestley \& David, 1912; David \& Priestley, 1914; Chapman, 1916;

191 Gordon, 1921; Hill, 1964; Breed, 1971; Rees, Pratt \& Rowell, 1989; Rowell \& Rees, 1989; Riding,

192 1991; Wrona \& Zhuravlev, 1996; Wrona, 2004); however, none come from the Mesozoic.

194 Comparison and affinities

195 The Fremouw Peak cyanobacterial filaments correspond in morphology to the fossil genus

196 Palaeolyngbya, a form taxon and repository for wide, unbranched, uniseriate fossil trichomes that

197 are composed of discoidal to cylindrical cells without any constrictions at the cross walls, and

198 enveloped in a prominent, uni- or multilayered, smooth sheath, and hence comparable in basic

199 organization to extant Lyngbya sensu lato (Oscillatoriaceae, Oscillatoriales; see Butterfield, Knoll

200 \& Swett, 1994: p. 60/61; Sergeev, Sharma \& Shukla, 2012: p. 300). The main criterion used to

201 discriminate species of Palaeolyngbya, according to Butterfield, Knoll \& Swett (1994: p. 61), is

202 the width of the uncollapsed sheath (i.e. filament width); for example, (sheath width in

203 parentheses) P. catenata $(10-30 \mu \mathrm{m})$ and $P$. hebeiensis $(30-60 \mu \mathrm{m})$ (Butterfield, Knoll \& Swett,

204 1994), P. giganteus (42-85 $\mu \mathrm{m})$, P. helva $(11-14 \mu \mathrm{m})$, and P. barghoorniana $(\leq 15 \mu \mathrm{m})($ Sergeev,

205 Sharma \& Shukla, 2012), and P. kerpii (22->30 $\mu \mathrm{m})($ Krings, 2019). The sheaths of the Fremouw

206 Peak filaments are 17-31 $\mu \mathrm{m}$ wide and, thus, correspond best to the recently described P. kerpii 
207 from the Lower Devonian Rhynie chert. Assignment of the Triassic filaments to P. kerpii is

208 conceivable. However, P. kerpii is preserved as a body fossil providing detailed insights into

209 filament morphology, together with specific developmental details, whereas the Fremouw Peak

210 fossils represent mineral replacements that provide a fair image of the filament morphology, but

211 do not reveal any structural or developmental details. As a result, it is difficult, if not impossible,

212 to determine whether the latter correspond to P. kerpii or belong to a different fossil species.

213 Therefore, we include the Fremouw Peak filaments in open nomenclature as Palaeolyngbya sp.

215 Cyanobacteria in Triassic permineralized peat

216 One reason for the lack hitherto of documented evidence of cyanobacteria in the Triassic

217 permineralized peat from Fremouw Peak may be that these minute life forms simply have been

218 overlooked in cursory screenings of peels or thin sections at low magnification. Moreover, the

219 quality of plant fossils preserved in the peat matrix depends largely on their condition (i.e. alive

220 and fully intact, moribund but still attached, or abscised and in the process of degradation) at the

221 time of permineralization. Evidence of microbial life appears to be generally rare in regions of the

222 peat that contain well-preserved plant remains, but rather occurs in peat comprising (partially)

223 degraded and tattered plant material not worthwhile for investigators interested in the plants and,

224 thus, are often not seen (Taylor \& Krings, 2010). On the other hand, the Fremouw Peak

225 permineralized peat is interpreted to have developed in a three-step process (Schopf, 1971; Taylor,

226 Taylor \& Collinson, 1989), through which fragile structures may have been altered secondarily or

227 destroyed (Harper et al., 2018). Finally, the lack of evidence for these organisms from

228 permineralized peat elsewhere, (e.g. DiMichele \& Phillips, 1994; Galtier, 2008; McLoughlin \&

229 Strullu-Derrien, 2015; Slater, McLoughlin \& Hilton, 2015), could mean that peat-forming 
230 paleoenvironments were perhaps generally not conducive to the preservation of cyanobacteria.

231 The scarcity of cyanobacterial fossil in peat deposits stands in stark contrast to silicified

232 geothermal hot spring (sinter) deposits, which often yield diverse assemblages of structurally

233 preserved cyanobacteria (e.g. Guido et al., 2010; García Massini et al., 2012; Hamilton et al., 2019;

234 Krings, 2019; Krings \& Harper, 2019; Krings \& Sergeev, 2019). Nothing is known to date about

235 the possible influence of a hydrothermal system on the silicification process at Fremouw Peak

236 (Taylor, Taylor \& Collinson, 1989).

237 Cyanobacterial filaments have only been detected in the whitish hyphal masses produced

238 by Endochaetophora antarctica around individual Dicroidium leaves on the forest floor (Harper,

239 2015). Because the filaments are salient structures, we rule out the possibility that they have been

240 overlooked in the peat matrix surrounding the hyphal masses and in other types of fossils, such as

241 hollow plant axes or decayed leaves. This peculiar pattern of spatial distribution raises the question

242 as to why filaments are so abundant in the E. antarctica hyphal masses, but are absent (or cannot

243 be traced) outside these occurrences?

244 One possible explanation is that a special micro-environmental setting was imperative for

245 the filaments to become preserved intact. Research on fragile microorganisms, including

246 cyanobacteria, exquisitely preserved elsewhere has provided evidence to suggest that certain

247 micro-environmental settings (e.g. amber, walls of leech cocoons, interiors of hollow plant axes,

248 small voids in the substrate, or microbial mat frameworks) had a cushioning effect on destructive

249 mechanical forces, and hence were effective as microscopic conservation traps for delicate

250 microbial life (Dörfelt, Schmidt \& Wunderlich, 2000; Bomfleur et al., 2012, 2015; McLoughlin et

251 al., 2016; Krings et al., 2018; Krings \& Harper, 2019; Krings \& Kerp, 2019). It is highly probable

252 that special circumstances also were in play during the fossilization of the cyanobacteria from 
253 Fremouw Peak. The hyphal masses, which are embedded in what appears to be a gelatinous matrix,

254 may have served as a conservation trap by shielding the filaments from destructive mechanical

255 forces, such as water movement and the taphonomic processes during peat formation, compaction,

256 and permineralization. Moreover, certain substances excreted by the fungal hyphae into the

257 surrounding matrix may have been biocidal and slowed down biological decomposition, or

258 somehow facilitated the process of mineral replacement. If all this is accurate, then it raises

259 another, equally difficult and probably even more complex question, namely as to why

260 cyanobacterial filaments occur in large numbers within hyphal masses produced by a fungus.

261 Cyanobacteria in general (Dickinson, 1983; Zadorina et al., 2009; Andersen, Chapman \&

262 Artz, 2013), and certain members of Lyngbya in particular (Karosienė \& Kasperovičienè, 2009;

263 Koreivienė \& Kasperovičienè \& Karosienè, 2009), are constituents of modern peatland

264 environments, and it would not be surprising to find these organisms also in ancient peat-forming

265 ecosystems based on their geologic range. However, the opposite is the case. Palaeolyngbya

266 filaments (and other cyanobacteria) were perhaps common and widespread on the wet forest floor

267 covered in leaf litter interspersed with E. antarctica hyphal masses, in small pools of water, and

268 maybe even on tree surfaces, but were destroyed during peat formation and the fossilization

269 process, with the exception of those located within the protective confines of the hyphal masses

270 ("cyanobacteria everywhere hypothesis"; see Figure 6). On the other hand, metagenomic analyses

271 indicate that cyanobacteria represent a relatively small percentage of total microbial biomass in

272 modern peat ecosystems, namely $0-4 \%$ in peat bogs and $\sim 0.85 \%$ in tropical peat swamps (Gilbert

273 \& Mitchell, 2006; Kanokratana et al., 2011). Thus, it is also possible that Palaeolyngbya and other

274 cyanobacteria have not been recorded more extensively because they were rare elements in this 
275 type of paleoenvironment or occurred exclusively in certain areas of the ecosystem that are not

276 reflected by the silicified peat samples studied to date (see Krings \& Sergeev, 2019).

277

Although the systematic affinity of Endochaetophora antarctica remains unresolved,

278

279

280

281

282

283

284

285

286

287

288

289

290

291

292

293

294

295

296

several authors have suggested it may belong to the Mucoromycota (see discussion by Krings, Taylor \& Dotzler, 2013). Specimens of another fossil fungus from Fremouw Peak, Jimwhitea circumtecta, provide the most persuasive fossil example of spores forming within a sporocarp and embedded in what is commonly termed a gleba (Krings et al., 2012: fig. 2B-C). The hyphal masses of E. antarctica are certainly not glebae in the strict sense of the definition (i.e. the central, internal portion of a fruiting body; see Ulloa and Hanlin, 2012: p. 252), but may be analogous structures within which the reproductive units formed. The chemical composition of glebae in Mucoromycota is virtually unknown; however, glebae of certain present-day Basidiomycota are composed primarily of amino acids and proteins (Oliveira \& Morato, 2000). It is, therefore, a possible, although highly speculative alternative premise at this time, that the cyanobacteria were attracted to the components of the E. antarctica hyphal masses and therefore migrated into these structures ("cyanobacteria migration hypothesis"; see Figure 7). Bearing in mind that the water in peat-forming environments today is generally nutrient-poor and of low $\mathrm{pH}$, it is possible to envision that the cyanobacteria would gravitate towards nutritionally dense resources. Moreover, it has been shown that, under certain stimuli or in high stress environments, some present-day filamentous cyanobacteria actively migrate towards and assimilate specific amino acids (Gallucci \& Paerl, 1983; Michelou, Cottrell \& Kirchman, 2007).

\section{A symbiosis?}

Peer) reviewing PDF | (2019:12:43944:1:1:NEW 9 Jan 2020) 
297 No direct evidence has been found to date that is suggestive of an interaction between the

298 Palaeolyngbya filaments and Endochaetophora antarctica, nor has the nutritional mode of $E$.

299 antarctica been deciphered. Nevertheless, the consistent co-occurrence of these two organisms

300 begs the question as to whether this peculiar alliance may also have included some form of 301 mutualism or parasitism. Mutualistic relationships between filamentous cyanobacteria and fungi

302 today occur in the form of lichens (Hawksworth, 1988). The Fremouw Peak fossils concur with 303 some of the criteria outlined by Lücking and Nelsen (2018: p. 552) for the identification of fossil

304 lichens; the most important criterion, however, namely a physiological interdependence between

305 the partners, cannot be evidenced. Another type of fungal symbiosis with filamentous

306 cyanobacteria occurs in Geosiphon pyriformis, a fungus in the Glomeromycota that produces

307 specialized bladders to harbor nitrogen-fixing cyanobacteria (Nostoc spp.) (Schüßler, 2002, 2012).

308 Palaeolyngbya is non-heterocystous; however, certain non-heterocystous filamentous

309 cyanobacteria, including Lyngbya under extremely stressful conditions, can also fix nitrogen

310 (Bergman et al., 1997). In addition, some authors include Geosiphon within Mucoromycota

311 (Glomeromycotina and Mucoromycotina) (Spatafora et al., 2016), to which also E. antarctica

312 probably belongs. We speculate that perhaps there were extinct members of the Mucoromycota

313 that formed non-lichen symbioses with cyanobacteria, and that the Geosiphon-Nostoc symbiosis

314 represents a relic of this type of fungus-cyanobacterial symbiosis (Schüßler, 2002), which not only

315 involved fungi interacting with endocytobiotic cyanobacteria, but perhaps also forms that house

316 their cyanobacterial symbionts in hyphal masses. On the other hand, there is also the remote

317 possibility that the fungus parasitized the cyanobacteria, which were somehow attracted into the

318 hyphal masses (e.g. Arora, Filonow \& Lockwood, 1983). 


\section{Conclusions}

321 Palaeolyngbya in the Triassic permineralized peat from Fremouw Peak provides the first evidence

322 of filamentous cyanobacteria from the Mesozoic of Antarctica. Moreover, the restricted occurrence

323 of the cyanobacterial filaments within hyphal masses produced by a fungus suggests that special

324 micro-environmental conditions have preserved these organisms in recognizable form, and that

325 the fungal hyphal masses have served as microscopic conservation traps for microbial life (sensu

326 Bomfleur et al., 2012). The recognition of cyanobacteria in microscopic conservation traps

327 provides a search image that now can be used to trace this and other types of microorganisms in

328 the vast amounts of permineralized peat that have been collected from Fremouw Peak. We

329 anticipate that other cyanobacteria will be discovered as further special micro-environmental

330 settings conducive to the preservation of microbial life are identified. The information obtained

331 from studying the microbial component of Antarctic Mesozoic paleoecosystems may help to

332 address questions pertaining specifically to the ecology of high-latitude plants and

333 paleoecosystems, including such aspects of whether the only fossil cycad that has been

334 documented to date from Antarctica, Antarcticycas schopfii (Hermsen, Taylor \& Taylor, 2009),

335 entered into a symbiotic relationship with cyanobacteria in a similar way as its relatives today (e.g.

336 Lindblad \& Bergman, 1990; Costa \& Lindblad, 2002; Tajhuddin et al., 2010).

\section{Acknowledgments}

339 We thank R. Serbet (Lawrence, KS, USA) for technical assistance, Benjamin Bomfleur (Münster,

340 Germany) for use and modification of Figure 1, D. Elliot (Columbus, OH, USA) for assistance

341 with mineralogy and Antarctic geology, A.-L. Decombeix (Montpellier, France) for fruitful

342 discussion, and the University of Kansas Interlibrary Loan department for help in procuring 
343 obscure literature. We thank our handling editor, C. Moyer (Bellingham, WA, USA), and two

344 anonymous referees for their constructive comments and suggestions.

345

346 References

347 Andersen R, Chapman SJ, Artz RRE. 2013. Microbial communities in natural and disturbed peatlands: A review. Soil Biology and Biochemistry 57:979-994. DOI: 10.1016/j.soilbio.2012.10.003

Arora DK, Filonow AB, Lockwood JL. 1983. Bacterial chemotaxis to fungal propagules in vitro and in soil. Canadian Journal of Microbiology 29:1104-1109. DOI: $10.1139 / \mathrm{m} 83-170$

352 Axsmith BJ, Taylor TN, Taylor EL. 1998. Anatomically preserved leaves of the conifer Notophytum krauselii (Podocarpaceae) from the Triassic of Antarctica. American Journal of Botany 85:704-713. DOI: $\underline{10.2307 / 2446541}$

355

356

Bergman B, Gallon JR, Rai AN, Stal, LJ. 1997. $\mathrm{N}_{2}$ fixation by non-heterocystous cyanobacteria. FEMS Microbiology Reviews 19:139-185. DOI: 10.1016/S0168-6445(96)00028-9

Bomfleur B, Kerp H, Taylor TN, Moestrup Ø, Taylor EL. 2012. Triassic leech cocoon from Antarctica contains fossil bell animal. Proceedings of the National Academy of the United States of America 109:20971-20974. DOI: 10.1073/pnas.1218879109

Bomfleur B, Decombeix A-L, Escapa IH, Schwendemann AB, Axsmith B. 2013. Whole-plant concept and environment reconstruction of a Telemachus conifer (Voltziales) from the Triassic of Antarctica. International Journal of Plant Sciences 174:425-444. DOI: $\underline{10.1086 / 668686}$

Bomfleur B, Decombeix A-L, Schwendemann AB, Escapa IH, Taylor EL, Taylor TN, McLoughlin S. 2014. Habit and ecology of the Petriellales, an unusual group of seed plants 
from the Triassic of Gondwana. International Journal of Plant Sciences 175:1062-1075. DOI: $\underline{10.1086 / 678087}$

368 Bomfleur B, Mörs T, Ferraguti M, Reguero MA, McLoughlin S. 2015. Fossilized spermatozoa preserved in a 50-Myr-old annelid cocoon from Antarctica. Biology Letters 11:20150431. DOI: $\underline{10.1098 / \mathrm{rsbl} .2015 .0431}$

371

Breed WJ. 1971. Permian stromatolites from Coalsack Col. Antarctic Journal of the United States 6(5):189-190.

Butterfield NJ, Knoll AH, Swett K. 1994. Paleobiology of the Neoproterozoic Svanbergfjellet Formation, Spitsbergen. Fossils and Strata 34:1-84. DOI: 10.1111/j.1502$\underline{3931.1994 . t b 01558 . x}$

Chapman F. 1916. Report on a probable calcareous alga from the Cambrian Limestone breccia found in Antarctica at $85^{\circ}$ South. Reports of the Scientific Investigations, British Antarctic Expedition, 1907-1909, Geology 2:81-84.

Costa JL, Lindblad P. 2002. Cyanobacteria in symbiosis in cycads. In: Rai AN, Bergman B, Rasmussen U, eds. Cyanobacteria in symbiosis. Dordrecht: Kluwer Academic, 195-206. DOI: $10.1007 / 0-306-48005-0 \quad 11$

Cúneo NR, Taylor EL, Taylor TN, Krings M. 2003. In situ fossil forest from the upper Fremouw Formation (Triassic) of Antarctica: Paleoenvironmental setting and paleoclimate analysis. Palaeogeography, Palaeoclimatology, Palaeoecology 197:239-261. DOI: 10.1016/S0031$\underline{0182(03) 00468-1}$

David TWE, Priestley RE. 1914. Glaciology, physiography, stratigraphy, and tectonic geology of South Victoria Land. Reports of the Scientific Investigations, British Antarctic Expedition, 1907-1909, Geology 1:241. 
389 Decombeix A-L, Bomfleur B, Taylor EL, Taylor TN. 2014. New insights into the anatomy, 390 development, and affinities of corystosperm trees from the Triassic of Antarctica. Review 391 of Palaeobotany and Palynology 203:22-34. DOI: 10.1016/j.revpalbo.2014.01.002

392 Dickinson CH. 1983. Micro-organisms in peatlands. In: Gore AJP, ed. Mires: swamp, bog, fen and 393 moor: regional studies. Ecosystems of the world, Series 4B. Amsterdam: Elsevier Scientific, 225-245.

DiMichele WA, Phillips TL. 1994. Paleobotanical and paleoecological constraints on models of 396 peat formation in the Late Carboniferous of Euramerica. Palaeogeography, Palaeoclimatology, Palaeoecology 106:39-90. DOI: 10.1016/0031-0182(94)90004-3

Dörfelt H, Schmidt AR, Wunderlich J. 2000. Rosaria succina spec. nov. - a fossil cyanobacterium from Tertiary amber. Journal of Basic Microbiology 40:327-332. DOI: 10.1002/15214028(20012)40:5/6<327::AID-JOBM327>3.0CO;2-E

Escapa IH, Taylor EL, Cúneo R, Bomfleur B, Bergene J, Serbet R, Taylor TN. 2011. Triassic floras of Antarctica: Plant diversity and distribution in high paleolatitude communities. PALAIOS 26:522-544. DOI: 10.2110/palo.2010.p10-122r

Elliot DH, Fanning CM, Isbell JL, Hulett SRW. 2017. The Permo-Triassic Gondwana sequence, central Transantarctic Mountains, Antarctica: Zircon geochronology, provenance, and basin evolution. Geosphere 13:155-178. DOI: $\underline{10.1130 / G E S 01345.1}$ 65:257-265. DOI: $\underline{10.1016 / 0034-6667(90) 90075-T}$

410 Faure G, Mensing TM. 2010. The Transantarctic Mountains: Rocks, Ice, Meteorites and Water. New York: Springer. DOI: $\underline{10.1007 / 978-90-481-9390-5 \_18}$ 
412 Gallucci KK, Paerl HW. 1983. Pseudomonas aeruginosa chemotaxis associated with blooms of

$413 \quad \mathrm{~N}_{2}$-fixing blue-green algae (Cyanobacteria). Applied and Environmental Microbiology $414 \quad 45: 557-562$.

415 Galtier J. 2008. A new look at the permineralized flora of Grand-Croix (Late Pennsylvanian, Saint416 Etienne Basin, France). Review of Palaeobotany and Palynology 152:129-140. DOI: 10.1016/j.revpalbo.2008.04.007

418 Galtier J, Phillips TL. 1999. The acetate peel technique. In: Jones TP, Rowe, NP, eds. Fossil Plants and Spores: modern techniques. London: Geological Society, 67-70.

420 García Massini J, Channing A, Guido DM, Zamuner AB. 2012. First report of fungi and fungus421 like organisms from Mesozoic hot springs. PALAIOS 27:55-62.

422 423 425

426

427

428

429

430

431

432

433 434 Earth Surface Processes 13:287-318. DOI: $\underline{\text { 10.1016/S0928-2025(06)09013-4 }}$

Gordon WT. 1921. Scottish National Antarctic Expedition, 1902-1904: Cambrian organic remains from a dredging in the Weddell Sea. Transactions of the Royal Society of Edinburgh 52:681-714. DOI: $\underline{\text { 10.1017/S0080456800015957 }}$

Guiry MD, Guiry GM. 2019. 'Lyngbya C. Agardh ex Gomont, 1892, nom. et typ. cons’ on AlgaeBase. World-wide electronic publication, National University of Ireland, Galway. Available at http://www.algaebase.org (accessed 9 October 2019).

Guido DM, Channing A, Campbell KA, Zamuner A. 2010. Jurassic geothermal landscapes and fossil ecosystems at San Agustín, Patagonia, Argentina. Journal of the Geological Society 167:11-20. DOI: 10.1144/0016-76492009-109

Hamilton AR, Campbell KA, Rowland JV, Barker S, Guido D. 2019. Characterisitcs and variations of sinters in the Coromandel Volcanic Zone: application to epithermal exploration. New 
Zealand Journal of Geology and Geophysics 62:531-549. DOI:

Hammer WR. 1990. Triassic terrestrial vertebrate faunas of Antarctica. In: Taylor TN, Taylor EL, eds. Antarctic Paleobiology: Its Role in the Reconstruction of Gondwana. New York: Springer-Verlag, 42-50. DOI: $10.1007 / 978-1-4612-3238-4 \_5$

Harper CJ. 2015. The diversity and interactions of fungi from the Paleozoic and Mesozoic of Antarctica. D. Phil. Thesis, University of Kansas.

Harper CJ, Taylor TN, Krings M, Taylor EL. 2015. Arbuscular mycorrhizal fungi in a voltzialean conifer from the Triassic of Antarctica. Review of Palaeobotany and Palynology 215:7684. DOI: 10.1016/j.revpalbo.2015.01.005

Harper CJ, Taylor TN, Krings M, Taylor EL. 2016. Structurally preserved fungi from Antarctica: Diversity and interactions in late Paleozoic and Mesozoic polar forest ecosystems. Antarctic Science 28:153-173. DOI: $\underline{10.1017 / \text { S0954102016000018 }}$

Harper CJ, Taylor EL, Walker C, White JF, Serbet R, Krings M. 2018. Fungal sporulation in a Permian plant fragment from Antarctica. Bulletin of Geosciences 93:13-26. DOI:

Hawksworth DL. 1988. The variety of fungal-algal symbioses, their evolutionary significance, and 10.3140/bull.geosci.1681

Hass H, Rowe NP. 1999. Thin sections and wafering. In: Jones TP, Rowe NP, eds. Fossil plants and spores: modern techniques. London: Geological Society, 76-81. 
456 Hermsen EJ, Taylor EL, Taylor TN. 2009. Morphology and ecology of the Antarcticycas plant.

Review of Palaeobotany and Palynology 153:108-123. DOI:

458 10.1016/j.revpalbo.2008.07.005

459

460

461

463

464

465

466

467

468

469

470

471

472

473

474

475

476

477

Hill D. 1964. Archaeocyatha from loose material at Plunkett Point at the head of Beardmore Glacier. In: Adie RJ, ed. Antarctic Geology. New York: Interscience Publishers, 609-622.

Jackson CR, Liew KC, Yule CM. 2009. Structural and functional changes with depth in microbial communities in a tropical Malaysian peat swamp forest. Microbial Ecology 57:402-412. DOI: $10.1007 / \mathrm{s} 00248-008-9409-4$

Joy KW, Willis AJ, Lacey WS. 1956. A rapid cellulose peel technique in palaeobotany. Annals of Botany 20:635-637. DOI: 10.1093/oxfordjournals.aob.a083546

Kanokratana P, Uengwetwanit T, Rattanachomsri U, Bunterngsook B, Nimchua T, Tangphatsornruang S, Plengvidhya V, Champreda V, Eurwilaichitr L. 2011. Insights into the phylogeny and metabolic potential of a primary tropical peat swamp forest microbial community by metagenomic analysis. Microbial Ecology 61:518-528. DOI: $\underline{10.1007 / \mathrm{s} 00248-010-9766-7}$

Karosienė J, Kasperovičienė J. 2009. Filamentous epiphyton cyanobacteria (Oscillatoriales, Nostocales) new to algal flora of Lithuanian freshwater. Botanica Lithuanica 15:79-91.

Kerp H, Bomfleur B. 2011. Photography of plant fossils—-New techniques, old tricks. Review of Palaeobotany and Palynology 166:117-151. DOI: 10.1016/j.revpalbo.2011.05.001

Knoll AH. 2008. Cyanobacteria and Earth history. In: Herrero A, Flores E, eds. The Cyanobacteria: molecular biology, genomics, and evolution. Norfolk: Caister Academic Press, 1-20. 
478 Komárek J, Kling H, Komárková J. 2003. Filamentous cyanobacteria. In: Wehr JD, Sheath RG, 479 eds. Freshwater algae of North America ecology and classification. London: 480 Elsevier/Academic Press Inc., 117-196. DOI: 10.1016/B978-012741550-5/5005-2

481 Komárek J, Kastovsky J, Mares J, Johansen JR. 2014. Taxonomic classification of 482 cyanoprokaryotes (cyanobacterial genera) 2014, using a polyphasic approach. Preslia 86:295-335.

484 Koreivienè J, Kasperovičienė J, Karosienė J. 2009. Cyanobacteria diversity in Kamanos raised bog (North-West Lithuania). Botanica Lithuanica 21:139-149. DOI: 10.1515/botlit-2015-0018

Krings M. 2019. Palaeolyngbya kerpii nov. sp., the largest filamentous cyanobacterium from the Lower Devonian Rhynie chert. PalZ 93:377-386. DOI: 10.1007/s12542-019-00475-w

Krings M, Harper CJ. 2019. A microfossil closely resembling Merismopedia (Cyanobacteria) from the 410-million-yr-old Rhynie and Windyfield cherts: Rhyniococcus uniformis revisited. Nova Hedwigia 108:17-35. DOI: 10.1127/nova hedwigia/2018/0507

Krings M, Kerp H. 2019. A tiny parasite of unicellular microorganisms from the Lower Devonian Rhynie and Windyfield cherts, Scotland. Review of Palaeobotany and Palynology 271:104016. DOI: $\underline{10.1016 / j . r e v p a l b o .2019 .104106}$

Krings M, Sergeev VN. 2019. A coccoid, colony-forming cyanobacterium from the Lower 496 Devonian Rhynie chert that resembles Eucapsis (Synechococcales) and Entophysalis

Krings M, Harper CJ, Kerp H, Taylor EL. 2018. Exceptional preservation of sessile, long-stalked microorganisms in the Lower Devonian Windyfield chert (Scotland). In: Krings M, Harper (Chroococcales), Review of Palaeobotany and Palynology 268:65-71. DOI: $\underline{10.1016 / j . r e v p a l b o .2019 .06 .002}$ CJ, Cúneo NR, Rothwell GW, eds. Transformative Paleobotany: Commemorating the life 
and legacy of Thomas N. Taylor. London: Elsevier/Academic Press Inc., 519-526. DOI:

502 $\underline{10.1016 / \mathrm{B} 978-0-12-813012-4.00021-8}$

503 Krings M, Taylor TN, Dotzler N, Persichini G. 2012. Fossil fungi with suggested affinities to the 504 Endogonaceae from the Middle Triassic of Antarctica. Mycologia 104:835-844. DOI: $\underline{10.3852 / 11-384}$

506

507

508

509

510

511

512

513

514

515

516

517

518

519

520

521

522

523

Krings M, Taylor TN, Dotzler N. 2013. Fossil evidence of the zygomycetous fungi. Persoonia 30:1-10. DOI: $\underline{10.3767 / 003158513 X 664819}$

Lindblad P, Bergman B. 1990. The cycad-cyanobacterial symbiosis. In: Rai AN, ed. Handbook of Symbiotic Cyanobacteria. Boca Raton: CRC Press, 137-159. DOI: $\underline{10.1201 / 9781351071185-6}$

Liu Z, Li H. 1986. Fossil blue-green algal community from the Upper Permian of Guangxi and its significant role in forming bottom of coal beds. Acta Micropalaeontologica Sinica 3:261272.

Lücking R, Nelsen MP. 2018. Ediacarans, protolichens, and lichen-derived Penicillium: A critical reassessment of the evolution of lichenization in fungi. In: Krings M, Harper CJ, Cúneo NR, Rothwell GW, eds. Transformative Paleobotany: Commemorating the life and legacy of Thomas N. Taylor. London: Elsevier/Academic Press Inc., 551-590. DOI: $\underline{10.1016 / B 978-0-12-813012-4.00023-1}$

Marsid EA, Sugiura N, Zakaria Z, Othman N, Utsumi M, Iwamoto K, Goto M, Hara H. 2015. Microbial diversity in disturbed and undisturbed peat swamp forest and isolation of cyanobacteria. In International Conference on Sustainability Initiatives (ICSI 2015) in conjunction with 8th ASEAN Environmental Engineering Conference (AEEC), 24-25 August, 2015, Kuala Lumpur, Malaysia. 
524 McLoughlin S, Strullu-Derrien C. 2015. Biota and palaeoenvironment of a high middle-latitude

525 Late Triassic peat-forming ecosystem from Hopen, Svalbard archipelago. Geological

526 Society, London, Special Publications 434:87-112. DOI: $\underline{10.1144 / \text { SP434.4 }}$

527 McLoughlin S, Bomfleur B, Mörs T, Reguero M. 2016. Fossil clitellate annelid cocoons and their 528 microbiological inclusions from the Eocene of Seymour Island, Antarctica. Palaeontologia 529 Electronica 19.1.11A:1-27. DOI: $\underline{10.26879 / 607}$

530 Michelou VK, Cottrell MT, Kirchman DL. 2007. Light-stimulated bacterial production and amino 531 acid assimilation by cyanobacteria and other microbes in the North Atlantic Ocean. 532 Applied and Environmental Microbiology 73:5539-5546. DOI: 10.1128/AEM.00212-07

533 Oliveira ML, Morato EF. 2000. Stingless bees (Hymenoptera, Meliponini) feeding on stinkhorn 534 spores (Fungi, Phallales): robbery or dispersal? Revista Brasileira de Zoologia 17:881884. DOI: $\underline{10.1590 / \mathrm{S} 0101-81752000000300025}$

Pigg KB. 1990. Anatomically preserved Dicroidium foliage from the central Transantarctic Mountains. Review of Palaeobotany and Palynology 66:129-145. DOI: $\underline{10.1016 / 0034-}$ $\underline{6667(90) 90031-D}$

Priestley RE, David TWE. 1912. Geological notes of the British Antarctic Expedition, 1907-1908. In C. R. $11^{\text {th }}$ International Congress on Geology, Stockholm 2:767-811.

Rees MN, Pratt BR, Rowell AJ. 1989. Early Cambrian reefs, reef complexes, and associated 542 lithofacies of the Shackleton Limestone, Transantarctic Mountains. Sedimentology 36:341-361. DOI: $10.1111 / \mathrm{j} .1365-3091.1989 . t b 00611 . \mathrm{x}$

Riding R. 1991. Cambrian calcareous Cyanobacteria and algae. In: Riding R, ed. Calcareous Algae and Stromatolites. Berlin: Springer-Verlag, 305-334. DOI: 10.1007/978-3-642-52335$\underline{9 \quad 16}$ 
547 Rowell AJ, Rees MN. 1989. Early Palaeozoic history of the upper Beardmore Glacier area:

548 Implications for a major Antarctic structural boundary within the Transantarctic

549 Mountains. Antarctic Science 1:249-260. DOI: 10.1017/S0954102089000374

550 Schopf JM. 1971. Notes on plant tissue preservation and mineralization in a Permian deposit of 551 peat from Antarctica. American Journal of Science 271:522-543. DOI:

$552 \quad \underline{10.2475 / a j s .271 .5 .522}$

553 Schopf JM. 1973. The contrasting plant assemblages from Permian and Triassic deposits in southern continents. In: Logan A, Hills LV, eds. The Permian and Triassic Systems and their mutual boundary. Memoirs of the Canadian Society of Petroleum Geology 2, 379397.

Schopf JW. 1968. Microflora of the Bitter Springs Formation, late Precambrian, central Australia. Journal of Paleontology 42:651-688.

Schopf JW. 2012. The fossil record of cyanobacteria. In: Whitton B, ed. Ecology of Cyanobacteria II. Dordrecht: Springer, 15-36. DOI: 10.1007/978-94-007-3855-3_2

Schüßler A. 2002. Molecular phylogeny, taxonomy, and evolution of Geosiphon 562 pyriformis and arbuscular mycorrhizal fungi. In: Smith SE, Smith FA, eds. Diversity and Integration in Mycorrhizas. Developments in Plant and Soil Sciences 94. Dordrecht: Springer, 75-83. DOI: $\underline{\text { 10.1007/978-94-017-1284-2 } 8}$

Schüßler A. 2012. The Geosiphon-Nostoc endosymbiosis and its role as a model for arbuscular mycorrhiza research. In: Hock B, ed. Fungal Associations. The Mycota (A Comprehensive Treatise on Fungi as Experimental Systems for Basic and Applied Research), vol. 9. Berlin: Springer, 77-91. DOI: 10.1007/978-3-642-30826-0 5 
569 Sergeev VN, Sharma M, Shukla Y. 2012. Proterozoic fossil cyanobacteria. Palaeobotanist 61:189$570 \quad 358$.

571 Sidor CA, Damiani R, Hammer WR. 2008. A new Triassic temnospondyl from Antarctica and a

572

573

574

575

576

577

578

579

580

581

582

583

584

585

586

587

588

589 review of Fremouw Formation biostratigraphy. Journal of Vertebrate Paleontology 28:656-663. DOI: 10.1671/0272-4634(2008)28[656:ANTTFA]2.0.CO;2

Slater BJ, McLoughlin S, Hilton J. 2015. A high-latitude Gondwanan lagerstätte: The Permian permineralised peat biota of the Prince Charles Mountains, Antarctica. Gondwana Res. 27:1446-1473. DOI: $10.1016 /$ j.gr.2014.01.004

Spatafora JW, Chang Y, Benny GL, Lazarus K, Smith ME, Berbee ML, Bonito G, Corradi N, Grigoriev I, Gryganskyi A, James TY, O’Donnell K, Roberson RW, Taylor TN, Uehling J, Vilgalys R, White MM, Stajich JE. 2016. A phylum-level phylogenetic classification of zygomycete fungi based on genome-scale data. Mycologia 108:1028-1046. DOI: $\underline{10.3852 / 16-042}$

Stankevica K, Kalnina L, Klavins M, Cerina A, Ustupe L, Kaup E. 2015. Reconstruction of the Holocene palaeoenvironmental conditions according to the multiproxy sedimentary records from Lake Plvelis, Latvia. Quaternary International 386:102-115. DOI: $\underline{10.1016 / \text { j.quaint.2015.02.031 }}$

Tajhuddin N, Muralitharan G, Sundaramoorthy M, Ramamoorthy R, Ramachandran S, Akbarsha MA, Gunasekaran M. 2010. Morphological and genetic diversity of symbiotic cyanobacteria from cycads. Journal of Basic Microbiology 50:54-265. DOI: $\underline{10.1002 / \text { jobm. } 200900343}$ 
590 Taylor EL, Taylor TN, Collinson JW. 1989. Depositional setting and paleobotany of Permian and $591 \quad$ Triassic permineralized peat from the central Transantarctic Mountains. International 592 Journal of Coal Geology 12:657-679. DOI: 10.1016/0166-5162(89)90068-2

593 Taylor TN, Krings M. 2010. Paleomycology: The rediscovery of the obvious. PALAIOS 25:283594 286. DOI: $\underline{10.2110 / p a l o .2010 . S 03}$

595 Taylor TN, Taylor EL, Collinson JW. 1986. Paleoenvironment of Lower Triassic plants from the 596 Fremouw Formation. Antarctic Journal of the United States 21(5):26-27. DOI: $\underline{10.1007 / 978-1-349-07805-9 \quad 4}$

598 Tomitani A, Knoll AH, Cavanaugh CM, Ohno T. 2006. The evolutionary diversification of 599 cyanobacteria: Molecular-phylogenetic and paleontological perspectives. Proceedings of the National Academy of the United States of America 103:5442-5447. DOI: $\underline{10.1073 / \text { pnas.0600999103 }}$

603 [American Phytopathological Society] Press.

604 Waggoner BM. 1994. An aquatic microfossil assemblage from Cenomanian amber of France. 605 Lethaia 27:77-84. DOI: $\underline{\text { 10.1111/j.1502-3931.1994.tb01559.x }}$

606 White JF, Taylor TN. 1988. Triassic fungus from Antarctica with possible Ascomycetous 607 608 affinities. American Journal of Botany 75:1495-1500. DOI: 10.1002/j.1537$\underline{2197.1988 . t b 11223 . x}$

609 White JF, Taylor TN. 1989. An evaluation of sporocarp structure in the Triassic fungus 610 Endochaetophora. Review of Palaeobotany and Palynology 61:341-345. DOI: 611 $\underline{10.1016 / 0034-6667(89) 90038-9}$ 
612 Wrona R. 2004. Cambrian microfossils from glacial erratics of King George Island, Antarctica. 613 Acta Palaeontologica Polonica 49:13-56.

614 Wrona R, Zhuravlev A Yu. 1996. Early Cambrian archaeocyaths from glacial erratics of King 615 George Island (South Shetland Islands), Antarctica. In: Gaidzicki A, ed. Palaeontological 616 Results of the Polish Antarctic Expedition. Part II. Palaeontologia Polonica 55:9-36.

617 Yule CM, Gomez LN. 2009. Leaf litter decomposition in a tropical peat swamp forest in Peninsular 618 Malaysia. Wetlands Ecology and Management 17:231-241. DOI: 10.1007/s11273-008$619 \quad \underline{9103-9}$

620 Zadorina EV, Siobodova NV, Boulygina ES, Kolganova TV, Kravchenko IK, Kuznetsov BB. 621 622 2009. Analysis of the diversity of diazotrophic bacteria in peat soil by cloning of the nifH gene. Microbiology 78:218-226. DOI: $\underline{10.1134 / S 0026261709020131}$

623

624

625 Figure captions

626 Figure 1. Geographic occurrence and stratigraphic position of the Fremouw Peak permineralized 627 peat; modified from Bomfleur et al. (2014: fig. 1). A. Overview of collection area in the Central 628 Transantarctic Mountains, South Victoria Land, Antarctica. B. Boxed area and arrow in Fig. 1A. 629 Detail of Fremouw Peak locality with arrow indicating collecting site. C. Stratigraphic column of 630 Fremouw Peak locality with arrow indicating position of permineralized peat.

631

632 Figure 2. Overview of Endochaetophora antarctica hyphal masses and Palaeolyngbya sp. in 633 permineralized peat. A. Three hyphal masses (arrows) in leaf mats (L); slide KUPB 35,009; scale 634 bar=1 cm. B. Higher magnification of Fig. 2A, showing hyphal mass (between arrowheads) and 
635 E. antarctica reproductive units (F); slide KUPB 35,009; scale bar $=500 \mu \mathrm{m}$. C. High magnification

636 of densely spaced hyphae comprising hyphal mass; arrows indicate septa; slide KUPB 35,017;

637 scale bar=10 $\mu \mathrm{m}$. D. Comparison of appendages (black arrows) of E. antarctica fungal 638 reproductive unit (F) to adjacent Palaeolyngbya filament (white arrow); slide KUPB 35,017; scale 639 bar $=50 \mu \mathrm{m}$. E. High magnification of E. antarctica appendage; portion of appendage extending 640 into hyphal mass and base of appendage in wall of E. antarctica (arrow); slide KUPB 35,018; scale 641 bar $=10 \mu \mathrm{m}$. F. Hyphal mass containing E. antarctica $(\mathrm{F})$ and fragmented cyanobacterial filaments; 642 note different mineral replacement, reddish-orange filaments (black arrows) and gray mineral 643 (white arrow); slide KUPB 35,009; scale bar $=250 \mu \mathrm{m}$. G. Hyphal mass with E. antarctica (F) and 644 long cyanobacterial filaments (arrows); slide KUPB 35,010; scale bar $=250 \mu \mathrm{m}$. H. Assemblage of 645 cyanobacterial filaments in hyphal mass; filaments in cross (black arrow) and longitudinal section 646 views (white arrow); slide KUPB 35,010; scale bar $=250 \mu \mathrm{m}$. I. Assemblage of cyanobacterial 647 filaments preserved as reddish-orange mineral replacements; note detail of discoid cells (arrow); 648 slide KUPB 35,011; scale bar $=500 \mu \mathrm{m}$. J. Well preserved filament in hyphal mass (arrow); slide 649 KUPB 35,009; scale bar $=500 \mu \mathrm{m}$.

650

651 Figure 3. Range of preservation states of cyanobacterial filaments. All scale bars $=50 \mu \mathrm{m}$. A. Clear 652 mineral replacement with barely visible discoid cells. Note rounded (possible) filament tip; slide 653 KUPB 35,009. B. Clear mineral replacement with discoid cells well recognizable; slide KUPB 654 35,009. C. Reddish-orange mineral replacement; slide KUPB 35,011. D. Cell lumina filled with 655 opaque matter; slide KUPB 35,010. E. Filaments with fine granular opaque matter; slide KUPB $65635,010$. 
658 Figure 4. Details of Palaeolyngbya sp. filaments. A. Overview of trichome with prominent sheath 659 (arrowheads) and discoid cells (arrow); slide KUPB 35,009; scale bar=50 $\mu \mathrm{m}$. B. Filament portion 660 with possible necridium (arrow); slide KUPB 35,009; scale bar=50 $\mu \mathrm{m}$. C. High magnification of 661 Fig. 4A, showing filament with discoid cells (black arrow) and prominent sheath (arrowheads); 662 slide KUPB 35,009; scale bar=10 $\mu \mathrm{m}$. D. Filament with constriction (arrow); slide KUPB 35,012; 663 scale bar=50 $\mu \mathrm{m}$. E. High magnification of constriction in Fig. 4D; slide KUPB 35,012; scale 664 bar $=5 \mu \mathrm{m}$. F. Filament showing portion of trichome in which cells are not preserved (arrow); slide 665 KUPB 35,012; scale bar $=50 \mu \mathrm{m}$.

666

667 Figure 5. Association of Endochaetophora antarctica with Palaeolyngbya sp. in permineralized 668 peat. A. Photograph of Endochaetophora antarctica and Palaeolyngbya sp. in permineralized peat. 669 B. Graphical representation of association between Endochaetophora antarctica and Palaeolyngbya sp. in permineralized peat. Scale bars $=500 \mu \mathrm{m}$.

671

672 Figure 6. Graphical representation of "cyanobacteria everywhere" hypothesis. A. Filaments occur 673 everywhere in matrix and hyphal mass. B. Filaments not preserved in peat but in hyphal mass. C. 674 Filaments found exclusively in hyphal mass. Scale bars $=500 \mu \mathrm{m}$.

675

676 Figure 7. Graphical representation of the "cyanobacteria migration" hypothesis. A. Filaments 677 occur exclusively in matrix. B. Filaments migrate into hyphal mass. C. Filaments found 678 exclusively in hyphal mass. Refer to key in Figure 6. Scale bars $=500 \mu \mathrm{m}$. 679 


\section{Figure 1}

Geographic occurrence and stratigraphic position of the Fremouw Peak permineralized peat; modified from Bomfleur et al. (2014: fig. 1).

A. Overview of collection area in the Central Transantarctic Mountains, South Victoria Land, Antarctica. B. Boxed area and arrow in Fig. 1A. Detail of Fremouw Peak locality with arrow indicating collecting site. C. Stratigraphic column of Fremouw Peak locality with arrow indicating position of permineralized peat. 

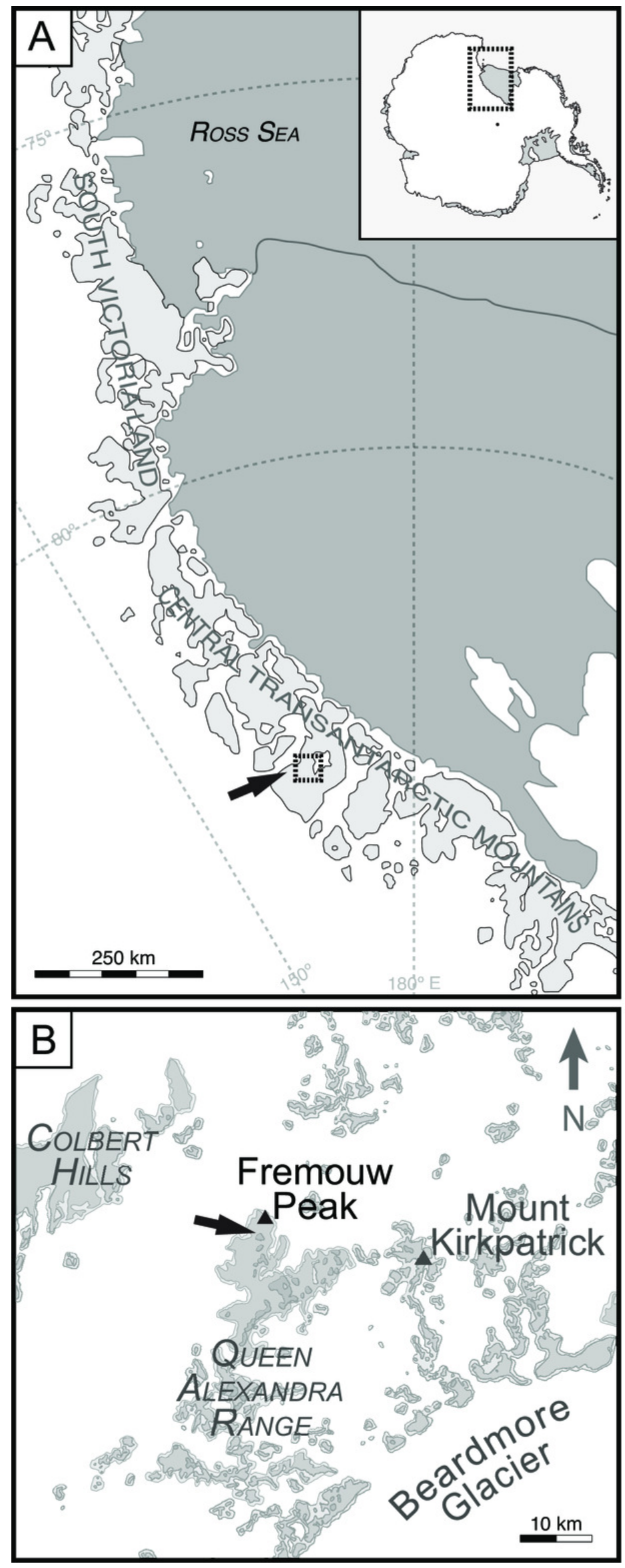

C

Fremouw Peak

(c. $84^{\circ} 17^{\prime} \mathrm{S} ; 1^{\circ} 4^{\circ} 32^{\prime} \mathrm{W}$ )

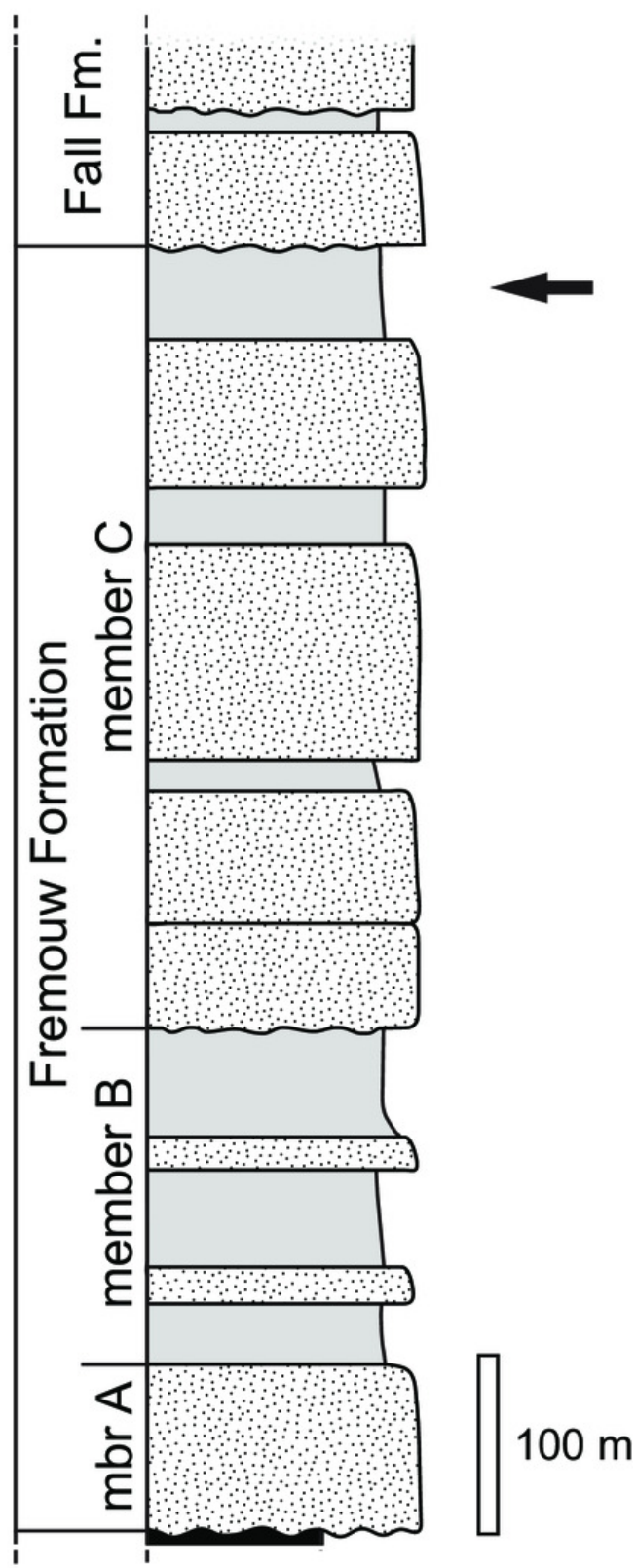

sandstone

mudstone

coal 


\section{Figure 2}

Overview of Endochaetophora antarctica hyphal masses and Palaeolyngbya sp. in permineralized peat.

A. Three hyphal masses (arrows) in leaf mats (L); slide KUPB 35,009; scale bar $=1 \mathrm{~cm}$. B. Higher magnification of Fig. 2A, showing hyphal mass (between arrowheads) and $E$. antarctica reproductive units (F); slide KUPB 35,009; scale bar=500 $\mu \mathrm{m}$. C. High magnification of densely spaced hyphae comprising hyphal mass; arrows indicate septa; slide KUPB 35,017; scale bar=10 $\mu$ m. D. Comparison of appendages (black arrows) of $E$. antarctica fungal reproductive unit (F) to adjacent Palaeolyngbya filament (white arrow); slide KUPB 35,017; scale bar=50 $\mu$ m. E. High magnification of $E$. antarctica appendage; portion of appendage extending into hyphal mass and base of appendage in wall of $E$. antarctica (arrow); slide KUPB 35,018; scale bar=10 $\mu$ m. F. Hyphal mass containing $E$. antarctica (F) and fragmented cyanobacterial filaments; note different mineral replacement, reddish-orange filaments (black arrows) and gray mineral (white arrow); slide KUPB 35,009; scale bar $=250 \mu \mathrm{m}$. G. Hyphal mass with $E$. antarctica (F) and long cyanobacterial filaments (arrows); slide KUPB 35,010; scale bar $=250 \mu \mathrm{m}$. H. Assemblage of cyanobacterial filaments in hyphal mass; filaments in cross (black arrow) and longitudinal section views (white arrow); slide KUPB 35,010; scale bar=250 $\mu \mathrm{m}$. I. Assemblage of cyanobacterial filaments preserved as reddish-orange mineral replacements; note detail of discoid cells (arrow); slide KUPB 35,011; scale bar=500 $\mu \mathrm{m}$. J. Well preserved filament in hyphal mass (arrow); slide KUPB 35,009; scale bar $=500 \mu \mathrm{m}$. 


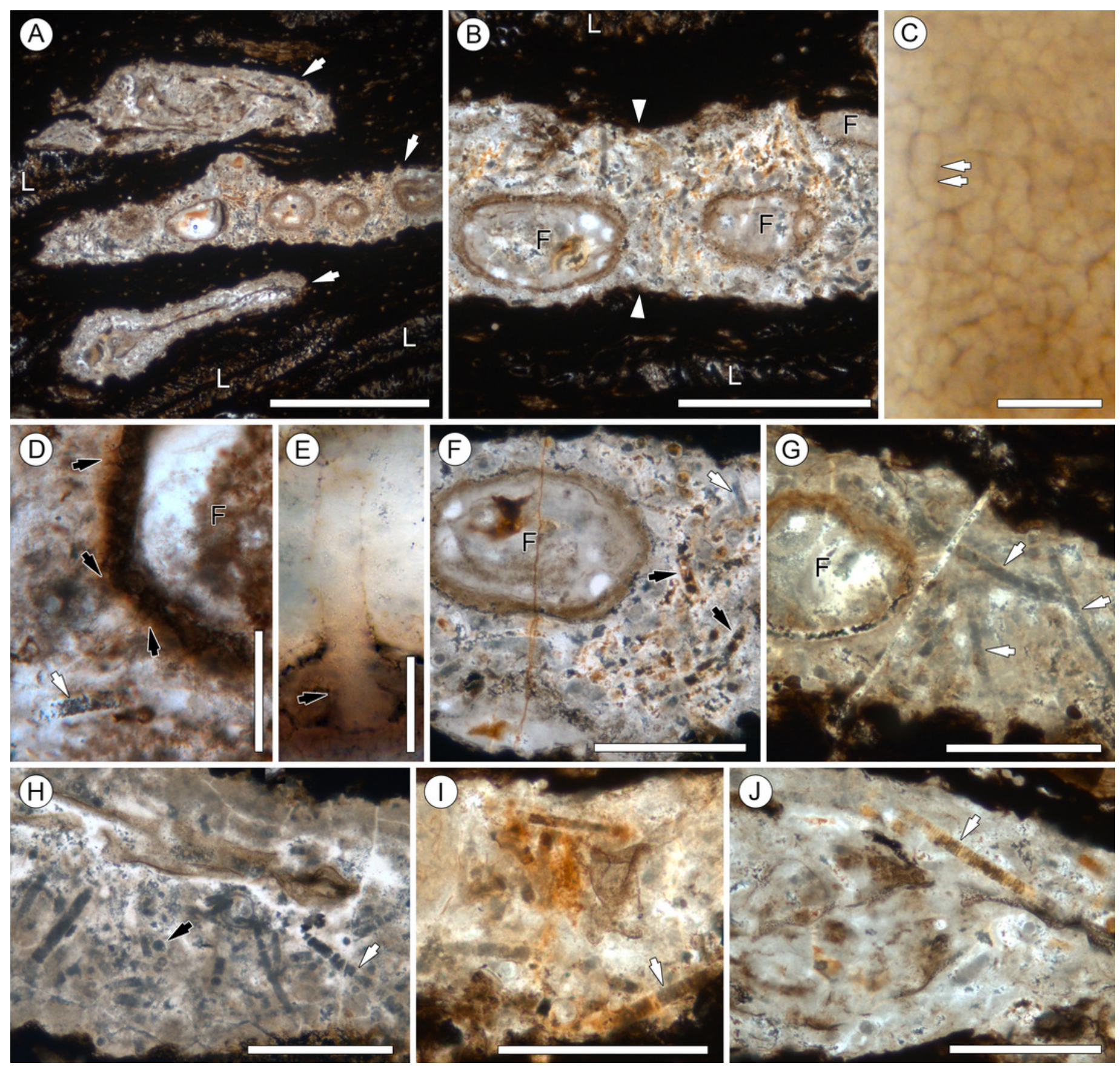




\section{Figure 3}

Range of preservation states of cyanobacterial filaments.

All scale bars $=50 \mu \mathrm{m}$. A. Clear mineral replacement with barely visible discoid cells. Note rounded (possible) filament tip; slide KUPB 35,009. B. Clear mineral replacement with discoid cells well recognizable; slide KUPB 35,009. C. Reddish-orange mineral replacement; slide KUPB 35,011. D. Cell lumina filled with opaque matter; slide KUPB 35,010. E. Filaments with fine granular opaque matter; slide KUPB 35,010.
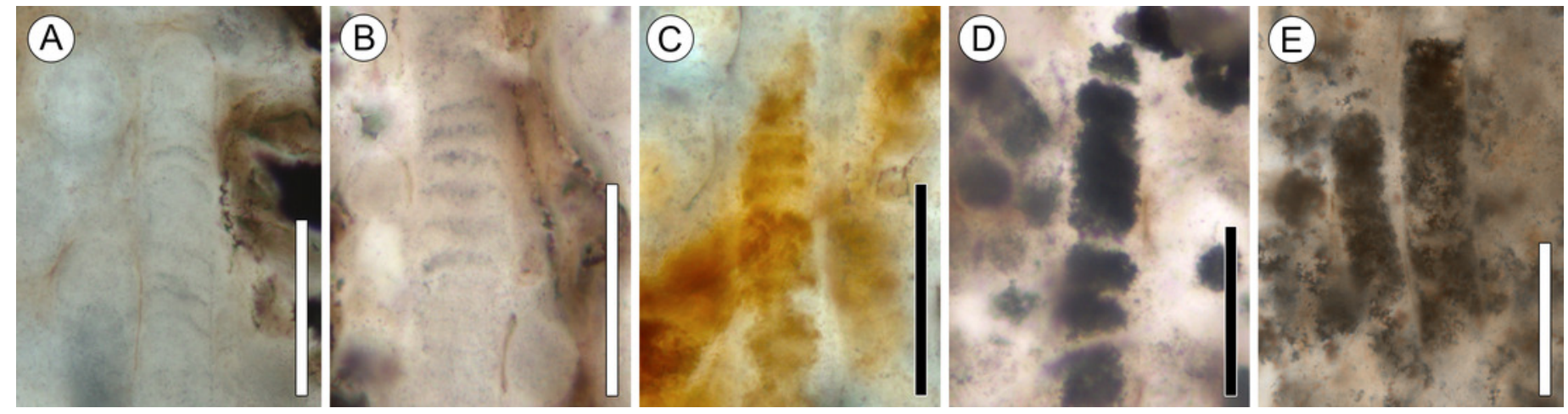


\section{Figure 4}

Details of Palaeolyngbya sp. filaments.

A. Overview of trichome with prominent sheath (arrowheads) and discoid cells (arrow); slide KUPB 35,009; scale bar $=50 \mu \mathrm{m}$. B. Filament portion with possible necridium (arrow); slide KUPB 35,009; scale bar=50 $\mu$ m. C. High magnification of Fig. 4A, showing filament with discoid cells (black arrow) and prominent sheath (arrowheads); slide KUPB 35,009; scale bar $=10 \mu \mathrm{m}$. D. Filament with constriction (arrow); slide KUPB 35,012; scale bar=50 $\mu \mathrm{m}$. E. High magnification of constriction in Fig. 4D; slide KUPB 35,012; scale bar $=5 \mu \mathrm{m}$. F. Filament showing portion of trichome in which cells are not preserved (arrow); slide KUPB 35,012; scale bar $=50 \mu \mathrm{m}$. 


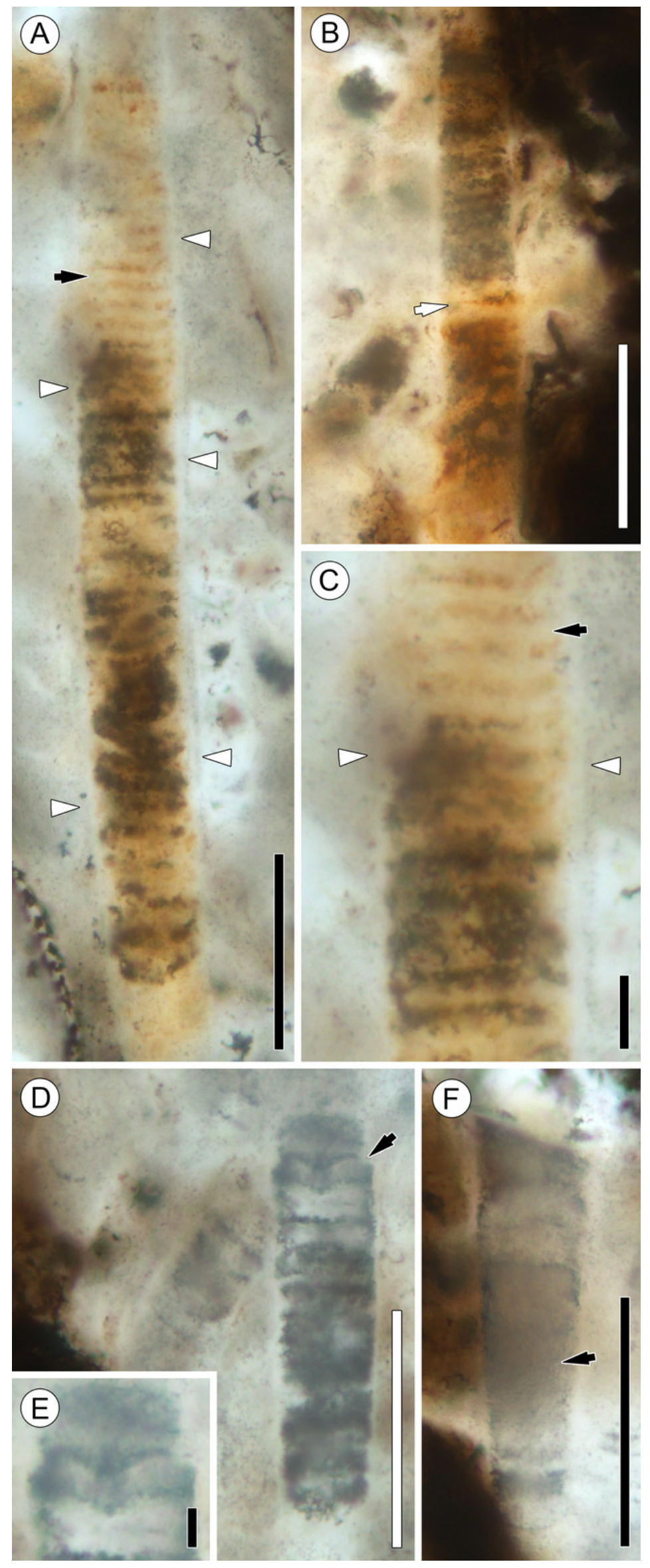

Peerj reviewing PDF | (2019:12:43944:1:1:NEW 9 Jan 2020) 
Figure 5

Association of Endochaetophora antarctica with Palaeolyngbya sp. in permineralized peat.

A. Photograph of Endochaetophora antarctica and Palaeolyngbya sp. in permineralized peat.

B. Graphical representation of association between Endochaetophora antarctica and Palaeolyngbya sp. in permineralized peat. Scale bars $=500 \mu \mathrm{m}$. 

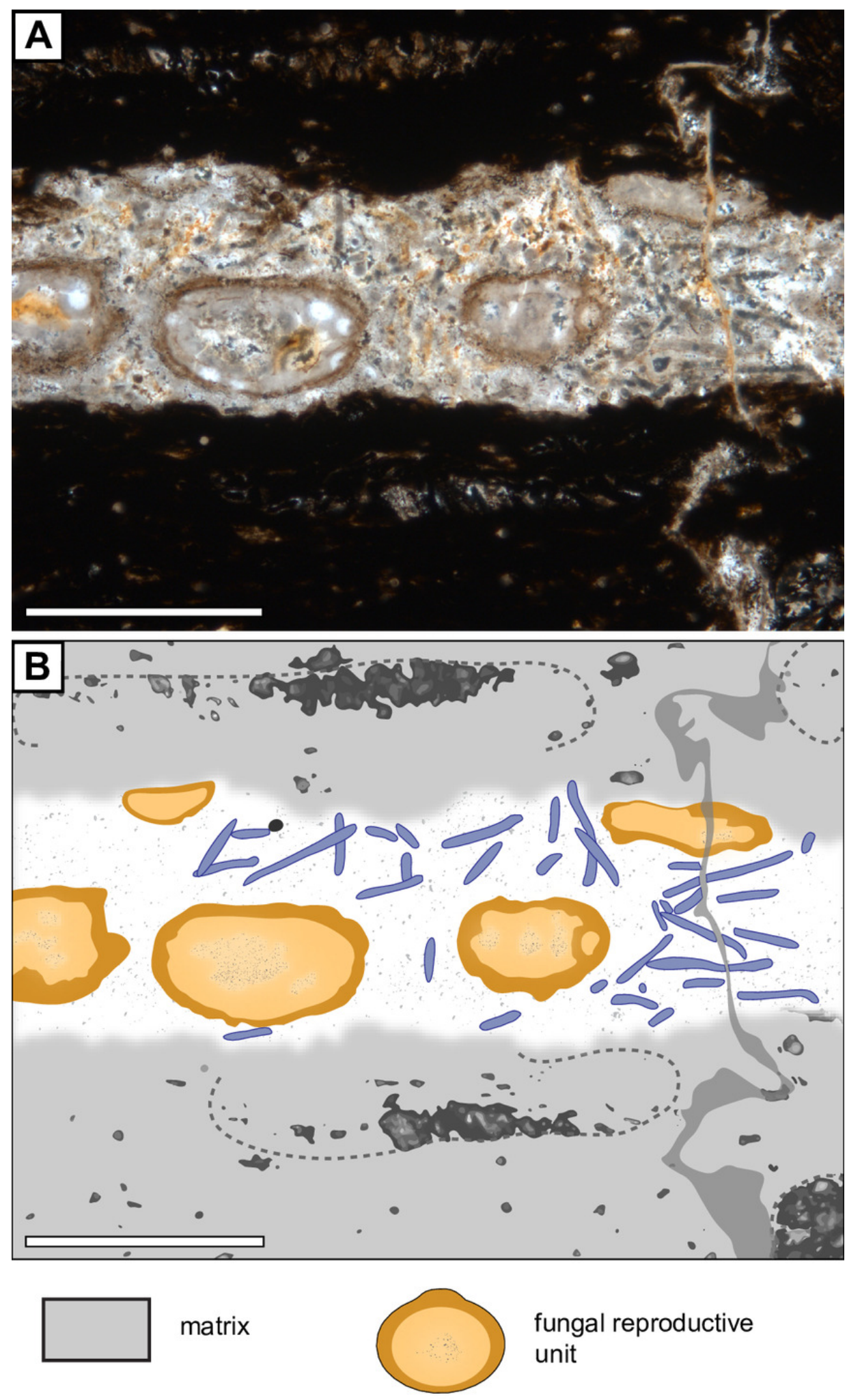

fungal reproductive

unit

hyphal mass

cyanobacteria filaments

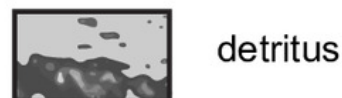

outline of degraded

Dicroidium leaf 
Figure 6

Graphical representation of "cyanobacteria everywhere" hypothesis.

A. Filaments occur everywhere in matrix and hyphal mass. B. Filaments not preserved in peat but in hyphal mass. C. Filaments found exclusively in hyphal mass. Scale bars=500 $\mu \mathrm{m}$.

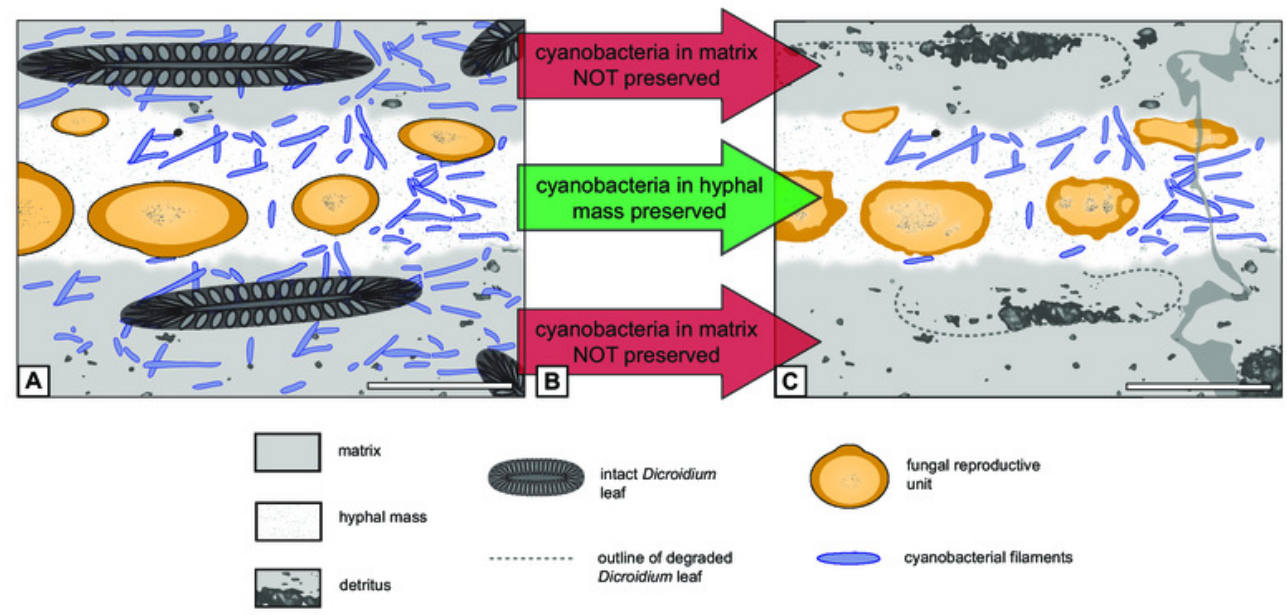


Figure 7

Graphical representation of the "cyanobacteria migration" hypothesis.

A. Filaments occur exclusively in matrix. B. Filaments migrate into hyphal mass. C.

Filaments found exclusively in hyphal mass. Refer to key in Figure 6. Scale bars $=500 \mu \mathrm{m}$.
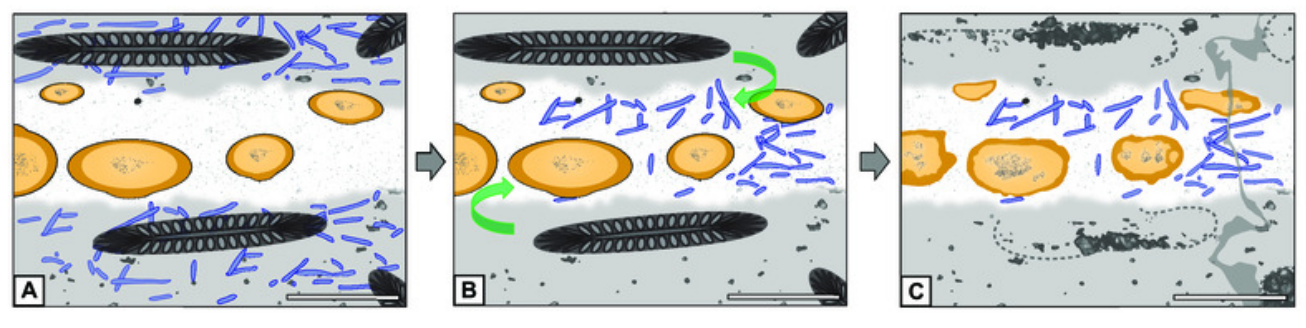